\title{
EVALUASI TINGKAT PELAYANAN JALAN KOTA MAKASSAR (Studi Kasus Ruas Jalan Arief Rate)
}

\author{
St. Maryam.H ${ }^{1}$, Lambang Basri Said ${ }^{2}$, Samsuddin ${ }^{3}$ \\ ${ }^{1}$ Dosen Jurusan Teknik Sipil Universitas Muslim Indonesia (UMI) \\ Jalan Urip Sumoharjo No.225 Makassar, Telp. 454534 \\ ${ }^{2}$ Dosen Jurusan Teknik Sipil Universitas Muslim Indonesia (UMI) \\ Jalan Urip Sumoharjo No.225 Makassar, Telp. 454534 \\ ${ }^{3}$ Mahasiswa Program Pascasarjana Magister Teknik Sipil UMI . \\ Jl Urip Sumoharjo No.225 Makassar,Telp.454534, udhina72@gmail.com
}

\begin{abstract}
ABSTRAK
Penelitian ini bertujuan untuk menganalisis karakteristik lalulintas dan kinerja pelayanan ruas jalan Arief Rate Kota Makassar serta menganalisis alternatif skenario penanganan dalam memperoleh tingkat pelayanan yang tepat untuk solusi kemacetan lalu lintas di ruas jalan Arief Rate Kota Makassar. Metode analisis yang digunakan adalah Interactive model of analysis dengan tiga komponen seperti: seleksi data, penyajian data dan penyimpulan data yang mendeskripsikan identifikasi tentang faktor-faktor yang mempengaruhi tingkat kemacetan lalu lintas di sepanjang jalan Arief Rate, Kota Makassar beserta upaya yang harus dilakukan untuk mencegah dan mengurangi tingkat kemacetan lalu lintas di sepanjang jalan Arief Rate, Kota Makassar. Berdasarkan hasil penelitian ini menunjukan bahwa Jalan Arief Rate akan mengalami penurunan tingkat pelayanan ke tingkat pelayanan D dimana Arus mendekati tidak stabil, kecepatanmasihdapat dikendalikan, $\mathrm{V} / \mathrm{C}$ masih dapat di tolerir, akibat adanya lalu lintas yang pada pagi hari karena pengantaran anak sekolah dan aktivitas perkantoran, adanya bangkitan parkir pada badan jalan dan aktivitas hambatan samping serta pada siang hari karena kondisi penjemputan anak sekolah kondisi menngkat dengan tingkat pelayannan jalan meningkat menjadi 0,85 pada kategori $\mathrm{E}$ dimana arus tidak stabil kecepatan terkadang terhenti, permintaan sudah mendekati kapasitas.. Pada Sore hari tingkat pelayanan jalan menjadi kinerja pelayanan jalan meningkat ada pukul 16.00-17.00 dengan tingkat pelayanan 0.86 .
\end{abstract}

Kata Kunci: Karakteristik jalan, tingkat pelayanan jalan dan kemacetan.

\section{PENDAHULUAN}

Latar belakang

Luas Wilayah Kota Makassar tercatat $175,77 \mathrm{~km}$ persegi, yang merupakan pusat dari berbagai kegiatan di Kawasan Indonesia Timur diantaranya kegiatan bisnis, ekonomi, dan pemerintahan, dan lain-lain sebagainya, yang tersebar di beberapa Kecamatan yang ada di Kota Makassar, hal ini menandakan adanya kemajuan yang pesat dalam pembangunan, maka dampak langsung dari peningkatan tersebut adalah mendorong potensi pergerakan yang lebih dinamis, sehingga dengan adanya penggunaan lahan yang mempunyai kegiatan maka ikut mempengaruhi volume kendaraan yang ada di ruas jalan tersebut (Hukmiah, 2011).

Namun terkadang meningkatnya volume kendaraan tidak diimbangi dengan peningkatan kapasitas ruas jalan sehingga dampak langsung dari peningkatan tersebut adalah terjadinya kemacetan, 
kesemrautan dan bahkan kecelakaan lalu lintas. Fenomena ini dapat dilihat dari beberapa ruas jalan di Kota Makassar terutama pada jam-jam sibuk antara pukul 08.00-17.00 WITA.

Salah satu ruas jalan di Kota Makassar yang selalu mengalami kemacetan. Ruas Jalan Arief Rate, berdasarkan survey awal peneliti arus lalulintas Jl Arief Rate, Makassar terpantau padat merayap, pada ruas terdapat beberapa kegiatan yang cukup padat seperti salah satu daerah perkantoran, pusat pendidikan dan pertokoan serta lokasi yang cukup dekat dengan Mall Ratu Indah, kondisi lalu lintas yang tidak lancar yang terlihat lumpuh karena kemacetan yang terjadi, banyaknya kendaraan penjemput anak sekolah yang namak memadati Jalan sehingga menyebabkan kemacetan.

Tujuan Penelitian

Untuk dapat menyeselaikanpermasalahan yang terjadi, maka tujuan penelitian ini untuk mengevaluasi kinerja pelayanan jalan diruas jalan Arief Rate Kota Makassar untuk memberikan solusi terhadap kondisi kemacetan yang terjadi.

\section{Manfaat Penelitian}

Adapun manfaat dilakukannya penelitian ini diharapkan dapat memberikan sumbangan pemikiran kepada Pemerintah khususnya pengelola sistem transportasi darat (Organda,LLAJ, Dinas Perhubungan, Dispenda, dan instansi lainnya) sebagai salah satu masukan maupun pertimbangan dalam membuat dan menentukan kebijakan-kebijakan pengelolaan sistem transportasi darat Kota Makassar dan diharapkan dapat memberikan masukan atau sebagai bahan referensi bagi peneliti lain dalam melakukan penelitian pada masa yang akan datang.

\section{Karakteristik Lalu lintas}

Menurut Roger P. Roes, et.al. (2004), karaktersitik lalu lintas dijalan terdiri dari 3 (tiga) parameter utama yaitu:

a. Volume lalu lintas Volume lalu lintas adalah banyaknya kendaraan yang melintasi suatu titik di ruas jalan atau pada suatu lajur dalam interval waktu tertentu seperti setiap interval 15 menitan, 1.0 jam, dalam 1 hari bahkan dalam 1 tahun. Fluktuasi volume arus lalu lintas pada suatu ruas jalan dalam waktu yang singkat akan menjadi sangat penting untuk mengetahui kondisi operasional lalu lintas dalam rentang waktu pengamatan misalnya 15 menitan. Volume lalu lintas di ruas yang dihitung pada setiap interval waktu kurang dari 1.0 jam biasa disebut dengan Nilai Arus (Flow Rate).

b. Kecepatan lalu lintas Kecepatan merupakan parameter kedua yang menggambarkan karaktersitik lalu lintas di suatu jalan. Kecepatan didefenisikan sebagai jarak tempuh kendaraan pada suatu penggal jalan dibahagi dengan jarak tempuhnya dan biasanya dinyatakan dalam satuan $\mathrm{km} / \mathrm{jam}$. Kecepatan arus lalu lintas (S).

c. Kepadatan lalu lintas

Kepadatan lalu lintas adalah jumlah kendaraan yang menempati suatu panjang ruas jalan atau lajur yang biasanya dinyatakan dalam kendaraan per kilometer atau smp per km. Kepatan lalu lintas sangat sukar diukur secara langsung di lapangan sehingga Kepadatan lalu lintas diestimasi dari hubungan Kecepatan rata rata ruang (SMS) dengan Volume arus lalu.

\section{Tingkat Pelayanan Jalan (Level of Service)}

Menurut Robin et al. (2016) tingkat servis (L.O.S.) adalah ukuran kualitas yang menggambarkan kondisi operasional dalam arus lalu lintas, umumnya dalam hal layanan yang disediakan oleh jalan kepada pengguna. Penentuan L.O. di perkotaan sangat berbeda dengan konsepnya diterapkan di daerah pedesaan atau jalan yang tidak terputus.

Dimana perbandingan tersebut ditunjukkan dengan nilai Derajat Kejenuhan DS (Degree Of Saturation). Penentuan tingkat pelayanan jalan berdasarkan DS ditunjukkan pada tabel berikut: 
Tabel 2.3 Tingkat Pelayanan Jalan

\begin{tabular}{|c|l|c|}
\hline Tingkat Pelayanan & \multicolumn{1}{|c|}{ Karakteristik Lalulintas } & Batas LingkupV/C \\
\hline $\mathrm{A}$ & $\begin{array}{l}\text { Kondisi arus lalu lintas bebas dengan kecepatan } \\
\text { tinggi dan volume lalu lintas rendah. }\end{array}$ & $0.00-0.20$ \\
\hline $\mathrm{B}$ & $\begin{array}{l}\text { Arus stabil, tetapi kecepatan operasi mulai } \\
\text { dibatasi oleh kondisi lalu lintas. }\end{array}$ & $0.20-0.44$ \\
\hline $\mathrm{C}$ & $\begin{array}{l}\text { Arus stabil, tetapi kecepatan dan gerak } \\
\text { kendaraan dikendalikan }\end{array}$ & $0.45-0.74$ \\
\hline $\mathrm{D}$ & $\begin{array}{l}\text { Arus mendekati tidak stabil, kecepatan masih } \\
\text { dapatdikendalikan, V/C masih dapat di tolerir. }\end{array}$ & $0.75-0.84$ \\
\hline $\mathrm{E}$ & $\begin{array}{l}\text { Arus tidak stabil kecepatan terkadang terhenti, } \\
\text { permintaan sudah mendekati kapasitas. }\end{array}$ & $0.85-1.00$ \\
\hline $\mathrm{F}$ & $\begin{array}{l}\text { Arus dipaksakan, kecepatan rendah, } \\
\text { volume diatas kapasitas, antrian panjang (macet) }\end{array}$ & $\geq 1.00$ \\
\hline
\end{tabular}

Sumber: Manual Kapasitas Jalan Indonesia, 1997.

\section{Penelitian Terdahulu}

Tantin Pristyawati (2012) menunjukkan bahwa dengan adanya peningkatan jalan terjadi perubahan tingkat level of service (LOS) dari level C menjadi level B. Sedangkan kapasitas (capacity) jalan mengalami peningkatan dari 2660,61 smp/jam menjadi 4666,54 smp/jam tanpa median dan 5045,19 smp/jam. Kecepatan arus bebas dari 37,05 km/jam menjadi 42,29 km/jam tanpa median dan 45,46 $\mathrm{km} / \mathrm{jam}$ untuk jalan dengan adanya median.

Jayaratne et al (2016) menjelaskan bahwa jalan dua jalur merupakan bagian utama dari jaringan jalan Sri Lanka. Kemampuan untuk secara akurat memperkirakan kapasitas jalur dan Tingkat Layanan (LOS) adalah elemen kunci dalam perencanaan dan manajemen jalan raya, yang penting untuk mengembangkan jaringan jalan yang efisien.

Robin et al (2016) L.O. penentuan di daerah perkotaan atau jalan adalah berbeda dengan daerah pedesaan. Di daerah pedesaan L.O.S. didasarkan pada kepadatan, aliran, ruang headway dan lainnya. tetapi dalam kasus jalan-jalan perkotaan L.O. tekad sepenuhnya berdasarkan kecepatan perjalanan rata-rata, waktu tunda, berlari waktu dan jenis dan kelas jalan kota. Penghitungan lalu lintas harus dilakukan dalam interval waktu 15 menit. Lalu lintas maksimum 15 menit dikonversi dalam durasi per jam. Dan kemudian faktor jam puncak ditentukan harus 0,85 atau kurang untuk tingkat layanan $\mathrm{C}$.

\section{METODE PENELITIAN}

\section{Lokasi Penelitian}

Penelitian ini dilakukan di Jalan Arief Rate Kota Makassar. Adapun waktu yang digunakan untuk meneliti adalah kurang lebih dua bulan.

\section{Instrumen Penelitian}

Dengan Instrumen penelitian yang digunakan yakni: Pedoman observasi, Pedoman wawancara dan Kamera yang digunakan untuk mendokumentasikan objek penelitian di lapangan. Survey volume dan komposisi lalu lintas dilakukan dari persimpangan di Jalan Hasanuddin ,Jalan Karungrung dan jalan Arief Rate yaitu kendaraan yang lewat dalam kurung waktu tertentu. Perhitungan lalu lintas dilakukan dengan menghitung pergerakan pada pos-pos pengamatan yang telah ditentukan dengan interval waktu 15 menit selama 2 jam karena keterbatas sumber daya maka pada tiap pos suvey data diambil selama satu hari. Pengamatan dilaksanakan pada pukul 07.00-09.00, 12.00-14.00, dan 16.00-18.00.

Pada pengamatan ini juga dilakukan pengamatan pada kondisi persimpangan seperti pengamatan terhadap pengaturan lalu lintas yang ada, baik berupa rambu, marka dan pengaturan dari petugas lalu lintas dan hambatan samping yang ada di sepanjang ruas jalan tersebut. Pos-pos survey 
diletakan di empat titik terdiri pos untuk mengamati pergerakan lalulintas dan pos untuk mengamati hambatan samping di tiap-tiap kemacetan.

\section{Survei Pengumpulan Data:}

Data karakteristik lalu lintas Volume lalu lintas , Kecepatan lalu lintas $(\mathrm{S}=$ Kecepatan $(\mathrm{km} / \mathrm{jam}))$, $\mathrm{D}=$ Jarak tempuh $(\mathrm{km}.) \mathrm{T}=$ Waktu tempuh $(\mathrm{jam})$, kepadatan lalu lintas $(\mathrm{D}=$ Kepadatan lalu lintas $(\mathrm{smp} / \mathrm{km}) \mathrm{V}=$ Volume lalu lintas (smp/jam) SMS = Kecepatan Rerata Ruang $(\mathrm{km} / \mathrm{jam})$.) Data Geomtrik Jalan: - Data lebar jalan (W), Data lebar bahu jalan/trotoar, Data tipe Jalan Data Hambatan Samping: • Data jumlah kendaraan berhenti dan parker, Data jumlah pejalan kaki, Data jumlah kendaraan keluar masuk sisi jalan, Data jumlah kendaraan lambat Data Volume Lalu lintas: - Nilai Arus (Flow Rate) dalam interval 15-menitan. Pengolahan Data Lapang dan Analisis dan Pembahasan dengan MKJI 1997.

\section{HASIL DAN PEMBAHASAN}

\section{Hasil Penelitian}

\section{Analisis Karakteristik Jalan}

Jalan Arief Rate merupakan ruas jalan yang dalam kategori jenis jalan kolektor primer dengan tipe jalan empat lajur dengan dua arah (4/2), dimana lebar jalan sekita $\pm 16 \mathrm{M}$ dengan panjang jalan 250 meter dan lebar jalan \pm 17 meter dengan panjang jalan 220 meter dan disepanjang ruas jalan sudah tidak ditemukan bahu jalan, kecepatan normal kendaraan seharusnya $40 \mathrm{~km} / \mathrm{jam}$., disepanjang ruas jalan ini terdapat 2 simpang perempatan dan 1 simpang pertigaan yang menyebabkan aktivitas lalu lintas menjadi lebih berat. Berikut adalah data bangunan komersial yang ada di Koridor Jalan:

Tabel 1. Jumlah Bangunan Komersial di Jalan Arief Rate

\begin{tabular}{|c|l|c|c|}
\hline No. & \multicolumn{1}{|c|}{ Bangunan Komersil } & Jumlah & $\%$ \\
\hline 1 & Sekolah & 4 & 9.1 \\
\hline 2 & Café dan Warkop & 3 & 6.8 \\
\hline 3 & Pertokoan & 4 & 9.1 \\
\hline 4 & Rumah Makan & 7 & 15,9 \\
\hline 5 & Mini Market & 3 & 6.8 \\
\hline 6 & Bangunan Rumah & 9 & 20.5 \\
\hline 7 & Perbankan/ pekantoran & 7 & 15.9 \\
\hline 8 & ATM & 5 & 11.4 \\
\hline 9 & Shoowroom Yamaha & 1 & 2.3 \\
\hline 10 & RS Chatrina Both & 1 & 2.3 \\
\hline \multicolumn{2}{|c|}{ Total } & 48 & $100 \%$ \\
\hline
\end{tabular}

Sumber: Hasil Survey, 2019

Berdasarkan data tersebut, bangunan rumah mendominasi penggunaan lahan di jalan Arief Rate. Diamping itu banyaknya aktivitas perbankan, rumah makan, ATM serta bangunan lainnya menyebabkan aktivitas dijalan ini menjadi sangat tinggi, perkantoran, sekolah, pertokoan bahkan Rumah sakit yang ada di Jalan Arief Rate hanya memiliki ruang parkir yang terbatas sehingga di sebagian badan jalan di sepanjang jalan ini digunakan sebagai tempat parkir kendaraan. Kondisi tersebut menjadikan aktivitas lalu lintas menjadi terhambat yang menyebabkan kemacetan disepanjang jalan.

\section{Analisis Tingkat Pelayanan Jalan}

Tingkat pelayanan jalan dapat ditentukan dari nilai volume, kapasitas dan kecepatan. Pada suatu keadaan dengan volume lalu lintas yang rendah, pengemudi akan merasa lebih nyaman mengendarai kendaraan dibandingkan jika dia berada pada daerah tersebut dengan volume lalu lintas yang lebih besar. Ukuran efektivitas tingkat pelayanan jalan atau level of service (LOS) 
dibedakan menjadi enam kelas, yaitu dari A untuk tingkat paling baik sampai dengan tingkat $\mathrm{F}$ untuk kondisi terburuk.

Nilai arus lalu lintas pada jam puncak di Jalan Arief rate pada pagi cenderung lebih tinggi. Ini berarti jalan ini cenderung lebih ramai pada waktu pagi hari.terutama pada hari sekolah dan hari kerja dipagi hari dan siang hari serta sore hari pada jam pulang kantor. Aktivitas lalu lintas di Jalan Arief Rate di Kota Makassar pada pagi hari merupakan jam puncak dan siang hari disebabkan karena aktivitas pengantaran dan penjemputan anak sekolah di jalan tersebut dan banyaknya mobil yang parkir di sebagian badan jalan, serta aktivitas transportasi online yang dipesan untuk menjemput anak sekolah pada siang hari terkadang memenuhi halaman depan sekolah pada ruas jalan dan banyakanya aktivitas hambatan samping, kondisi ini menyebabkan tingkat pelayanan jalan menjadi kurang efektif sehingga menyebabkan kendaran menjadi sangat lambat bergerak atau terjadi kondisi macet. Berdasarkan data tersebut menunjukan bahwa volume lalintas tertinggi pada jam 07.00-09.00, dan pada siang hari pukul 12.00-13.00 merupakan jam puncak volume lalu lintas tertinggi.

Tingkat pelayanan Jalan Arief Rate Kota Makassar disajikan pada Tabel 4. Berdasarkan rekapitulasi tingkat pelayanan dengan informasi bahwa Jalan Arief Rate akan mengalami penurunan tingkat pelayanan ke tingkat pelayanan $\mathrm{F}$ akibat adanya lalu lintas yang pada pagi hari karena pengantaran anak sekolah dan aktivitas perkantoran, adanya bangkitan parkir pada badan jalan dan aktivitas hambatan samping serta pada siang hari karena kondisi penjemputan anak sekolah. Pada Sore hari tingkat pelayanan jalan menjadi E, dan pada malam hari tingkat pelayanan jalan menjadi kategori $\mathrm{C}$, jalan ini tetap harus mendapat perhatian serius karena nilai derajat kejenuhannya sudah mencapai nilai ambang batas atas Tingkat Pelayanan $\mathrm{F}$ dengan kata lain kondisi ini arus lalu lintas.

\section{Pembahasan}

Dari analisis hasil penelitian, maka dapat dianalisis tingkat karakteristik jalan dan tingkat pelayanan jalan pada Jalan Arief Rate Kota Makassar sebagai berikut: Tingkat pelayanan jalan pada jalan arief rate pada pagi hari. Jalan Arief Rate akan mengalami penurunan tingkat pelayanan ke tingkat pelayanan D dimana Arus mendekati tidak stabil, kecepatan masih dapat dikendalikan, V/C masih dapat di tolerir, akibat adanya lalu lintas yang pada pagi hari karena pengantaran anak sekolah dan aktivitas perkantoran, adanya bangkitan parkir pada badan jalan dan aktivitas hambatan samping serta pada siang hari karena kondisi penjemputan anak sekolah kondisi menngkat dengan tingkat pelayannan jalan meningkat menjadi 0,85 pada kategori $\mathrm{E}$ dimana arus tidak stabil kecepatan terkadang terhenti, permintaan sudah mendekati kapasitas.. Pada Sore hari tingkat pelayanan jalan menjadi kinerja pelayanan jalan meningkat ada pukul 16.00-17.00 dengan tingkat pelayanan 0.86.

Adapun alternatif skenario penanganan dalam memperoleh tingkat pelayanan yang tepat mengatasi atau mengurangi kemacetan lalu lintas di ruas jalan Arief Rate Kota Makassar yaitu hanya melalui rekayasa lalu lintas atau dengan menutup sebelah jalan dari perempatan jalan manggis, supaya aktivitas lalu lintas menjadi tidak berat dan kondisi lalu lintas di jalan arief rate dengan kondisi tingkat pelayan jalan yang lebih optimal serta keberadaan petugas lalu lintas sangat dibutuhkan untuk menangani kondisi lalu lintas di jalan tersebut.

\section{PENUTUP}

Berdasarkan data yang diperoleh dan hasil analisis yang dilakukan pada penelitian ini, maka dapat disimpulkan hal-hal sebagai berikut: 
1. Karakteristik jalan Arief Rate penggunahan lahan pada koridor Jalan Arief Rate sebagian bangunan rumah mendominasi penggunaan lahan di jalan Arief Rate. Diamping itu banyaknya aktivitas perbankan, rumah makan, ATM serta bangunan lainnya menyebabkan aktivitas dijalan ini menjadi sangat tinggi,

2. Adapun tingkat pelayanan jalan nilai arus lalu lintas pada jam puncak di Jalan Arief rate pada pagi cenderung lebih tinggi. Ini berarti jalan ini cenderung lebih ramai pada waktu pagi hari.terutama pada hari sekolah dan hari kerja dipagi hari dan siang hari serta sore hari pada jam pulang kantor. Aktivitas lalu lintas di Jalan Arief Rate di Kota Makassar pada pagi hari merupakan jam puncak dan siang hari disebabkan karena aktivitas pengantaran dan penjemputan anak sekolah di jalan tersebut dan banyaknya mobil yang parkir di sebagian badan jalan, serta aktivitas transportasi online/ gran atau gojek yang dipesan untuk menjemput anak sekolah pada siang hari terkadang memenuhi halaman depan sekolah pada ruas jalan dan banyakanya aktivitas hambatan samping, kondisi ini menyebabkan tingkat pelayanan jalan menjadi kurang efektif sehingga menyebabkan kendaran menjadi sangat lambat bergerak atau terjadi kondisi macet.

\section{DAFTAR PUSTAKA}

Anonim, 1997, Manual Kapasitas Jalan Indonesia (MKJI). Direktorat Jenderal Bina Marga, Jakarta.

Hukmia. 2011. Pengaruh Aktivitas Komersial Terhadap Lalu Lintas di Koridor Jalan Perintis Kemerdekaan.

Jayaratne, Nalin , Pradeep Rushan Jayasinghe, dan H.R. Pasindu. 2016. Evaluation of Level of Service for two-lane roads in Sri Lanka. https://www.researchgate.net/publication/309285341_Evaluation_of_Level_of_Service for t wo-lane roads in Sri_Lanka. Conference: IESL Annual Sessions 2016, At Colombo.

Julfikri M, 2003. Faktor-Faktor yang mempengaruhi Tundaan Lalu Lintas dan Biaya Yang Ditimbulkannya Di Kota Samarinda, Tesis. Program MTPK UNDIP.

Khairudin , Akhmad. 2016. Manajemen Rekayasa Lalu Lintas Jaringan Transportasi Menuju Pusat Kota Malioboro Yogyakarta Menggunakan Maximum Flow Technique. Tesis. Manajemen Universitas Gajah Mada.

Kumita, Sofyan M. Saleh, M. Isya. 2015. Manajemen Lalu Lintas Pada Jalan Teuku Abdurrahman Meunasah Meucap Sebagai Jalan Masuk Universitas Almuslim. Jurnal Teknik Sipil Volume 4, No. 1, Februari 2015, ISSN 2302-0253 Pascasarjana Universitas Syiah Kuala 12 Pages pp. 96107.

Meilany, Prihono. 2018. Evaluasi Rekayasa Lalu Lintas Di Bundaran Lalu Lintas (Studi Kasus: Bundaran Lalu Lintas Patung Sam Ratulangi). Jurnal Sipil Statik Vol.6 No.9 September 2018 (665-670) ISSN: 2337-6732

Q. Wang and C. F. Shao, "Evaluation of Signalized Intersection Service Level in the Traffic Impact Assessment", Advanced Materials Research, Vols. 869-870, pp. 327-333, 2014.

Robin Babit, Viranta Sharma, dan Ajay K. Duggal. 2016. Level Of Service Concept In Urban Roads. International Journal of Engineering Science Invention Research \& Development; Vol. III, Issue I, July 2016 www.ijesird.com, e-ISSN: 2349-6185.

Roger P., Roes, et. al., 2004, Traffic Engineering, 3rd, Pearson Education, Inc. New Jersey, USA. 
Tantin Pristyawati. 2012. Evaluasi Tingkat Pelayanan Jalan Jenderal Sudirman Kabupaten Sukoharjo. Volume XIII No.1 Maret 2012 ISSN : 977 - 19799705. 